\title{
瑞浪超深地層研究所研究坑道掘削工事における総合評価落札方式について
}

\author{
核燃料サイクル開発機構 \\ $\bigcirc$ 佐藤 稔紀* \\ 見掛 信一郎* \\ 今津 雅紀* \\ 坂巻 昌工*
}

Toshinori SATO, Shin-ichiro MIKAKE, Masanori IMAZU, Masanori SAKAMAKI

\begin{abstract}
樑度 $1,000 \mathrm{~m}$ の立坑 2 本と水平坑道から構成される瑞浪超深地層研究所は, 高レベル放射性廃棄物地層処 分技術に関する梁地層（対象岩盤：結晶質岩）の研究施設として，わが国で初めて建設されることとなっ た。瑞浪超深地層研究所研究坑道掘削工事の契約においては, 本事業の特殊性や透明性ならびに安全性や 技術の向上のために，一般競争入札のもと，総合評価落札方式を採用した。工区分けは，立坑各 1 本ずつ とし，提案事項は相互に仕様書に反映することで，より高度な施工が可能になるように考慮した。本稿に おいて，これらの契約方式を採用した経緯，内容および評価について示した。
\end{abstract}

キーワード : 立坑, 総合評価落札方式, 契約方式

1.はじめに

核燃料サイクル開発機構（以下，サイクル機構） が建設を計画している瑞浪超深地層研究所（以下， 研究所）は,「原子力の研究, 開発及び利用に関する 長期計画 (平成 12 年 11 月 24 日,原子力委員会)」 に示された深地層の研究施設のひとつであり, 結晶 質岩（花崗岩）を主な調査研究対象としている。研 究所は, 地表から地下 $1,000 \mathrm{~m}$ に及ぶ立坑や水平坑 道から構成され, 大深度に研究坑道を掘削するため の工学技術の適用性の評価および深部地質環境の総 合的な調查技術の開発の場としての役割を担うとと もに, 深地層に対する国民の理解促進の場としても その役割は大きい。また,ここでの研究に対しては, 地層処分技術に関する研究開発の基盤となるだけで なく, 地震研究や地下空間利用研究など, 深地層の 特性を生かす学術的な研究を幅広く行い, 国際協力 を含め, 関係する研究機関や大学などとの協力を進 めながら研究を実施することが求められている。

一方, 研究所が設置される場所は, 東濃研究学園 都市構想のインターガーデン用地内にあり, サイエ ンスワールド (岐阜県の体験型学習施設) や瑞浪化 石博物館など, 広く一般市民に開かれた施設が多い。 このような環境の中で, 研究所も一般市民に幅広く 門戸を開いた安全な施設であることが求められてい る。今回の瑞浪超深地層研究所研究坑道掘削工事 (以

*) 核燃料サイクル開発機構 東濃地科学センター 瑞浪超深地層研究所 施設建設グループ

(Tel : 0572-66-2244)
下, 研究坑道工事) は, 前述のような施設の位置づ けに鑑み，非常に重要度の高い工事である。

研究所は, 高レベル放射性廃棄物地層処分技術に 関する深地層の研究施設として, わが国で初めて建 設されものである。結晶質岩を研究対象とした当研 究所は, 深度 $1,000 \mathrm{~m}$ の立坑 2 本と水平坑道から構 成される。一方, 堆積岩を研究対象とした研究所と しては, 北海道幌延町において梁度 $500 \mathrm{~m}$ の立坑 3 本から構成される幌延深地層研究計画があり, その 研究計画が現在検討されている。

研究坑道工事の契約においては, 本事業の特殊性 や透明性ならびに安全性や技術の向上のために, 以 下の契約方式を採用した。

- 一般競争入札

- 工区分け

- 総合評価落札方式

・ 積算価格の事前公表

上記の契約方式について，工区分け以外はサイク ル機構として初めて採用したものである。以上のこ とより, 本稿に扮いては, 工事の概要を述べた上で, 総合評価落札方式を採用した経緯や内容および評価 について示すことにより, 今後の同様な工事契約に 資することを目的とする。

\section{2. 研究坑道工事の概要}

(1) 工事概要

研究所の研究坑道建設は, 2009 年度末までに深度 $1,000 \mathrm{~m}$ 程度に到達する計画であり, 研究坑道建設 に必要な設備は, 深度 $1,000 \mathrm{~m}$ の掘削に耐えるもの 
としている。その主な工種は, 以下の通りである。

・仮設備および坑内設備・坑外設備 一式

- 主立坑 $\mathrm{L}=1,025 \mathrm{~m}$ (仕上り内径 $\phi 6.5 \mathrm{~m}$ )

- 換気立坑 $\mathrm{L}=1,010 \mathrm{~m}$ (仕上り内径 $\phi 4.5 \mathrm{~m}$ )

- 扇風機坑道 一式

（立坑 $\mathrm{L}=29 \mathrm{~m}$, 横坑 $\mathrm{L}=4.8 \mathrm{~m}$ )

・予備ステージ 9 箇所（概ね $100 \mathrm{~m}$ ごと）

- 計測坑道 3 䇢所

（深度 $470 \mathrm{~m}, 530 \mathrm{~m}, 970 \mathrm{~m}$ 地点）

・中間ステージ 一式

(深度 $500 \mathrm{~m}$ 地点 /ループ坑道, 試錐座,

連絡坑道, 試験坑道, TBM 坑道含む)

・最深ステージ 一式

(深度 $1,000 \mathrm{~m}$ 地点 /中間ステージと同様)

- 計測工 一式

\section{（2）工事内容}

坑道の掘削は, 当初, 地上設備の基礎部分（坑口 上部工 : 地表 GL-0m〜約 GL-10m区間）を施工し, 坑内でスカフォード等の掘削設備を組立てるための 坑口下部工 (約 GL-10m〜約 GL-50m区間)を行う。 その後, 主立坑および換気立坑の一般部掘削（約 GL-50m 以深）を行う。立坑一般部の掘削は, 全断 面発破と覆エコンクリート打設を繰り返すショート ステップエ法にて行うこととした。

地上施設としては, 立坑巻き上げ機・櫓設備, 給 排水設備, 排水処理設備, 換気設備, コンクリート プラント，電気設備およびこれらを収納する防音八 ウス, また火工所などの掘削に必要な付帯設備等で ある。水平坑道の掘削は, 全断面発破工法で行い, 岩盤等級に応じて吹付けコンクリートやロックボル 卜等による支保を行う。水平坑道のうち, 中間ステ ージ（深度 $500 \mathrm{~m}$ に設置）と最深ステージ（深度約 $1,000 \mathrm{~m}$ に設置）の一部では，直径約 $2.2 \mathrm{~m}$ の TBM (Tunnel Boring Machine) による掘削も行う予定 である 1)。

研究坑道工事は, 一般のトンネル工事と異なり, 地層科学研究の一環として掘削されるものであり, 立坑掘削中も壁面観察などの目的で掘削の 1 サイク ル (下部工で $1 \mathrm{~m}$, 一般部で $2.6 \mathrm{~m}$ ) 毎に, 一定期間, 研究者が入坑することとした。

(3) 工区分け

一般的なトンネルやダムなどの大規模工事におい ては, 工区分けにて分割発注されることが一般的で ある。研究坑道工事においても, 一般的なトンネル 工事と同様に, 一期工事分 (立坑 $300 \mathrm{~m}$ 分, 工期約 3 年間) について, 図一 1 に示すように A 工区（主
立坑）と B 工区（換気立坑）の 2 つの工区に分割し た。当該工事は, 地下研究施設としてだけでなく土 木工事としても, 世界最長の大深度の構造物を構築 するものである。工区分けのメリットとしては，契 約後においても技術的競争意識が工区ごとに生まれ， より高い品質を目指すことができることである。一 方, デメリットとしては, 工法・仕様等の統一・調 整事項が多くなる負担の増加に加え, A 工区・B工 区共通施設である排水処理設備および電気設備など は相手工区の工程に影響を与えることがあげられる。

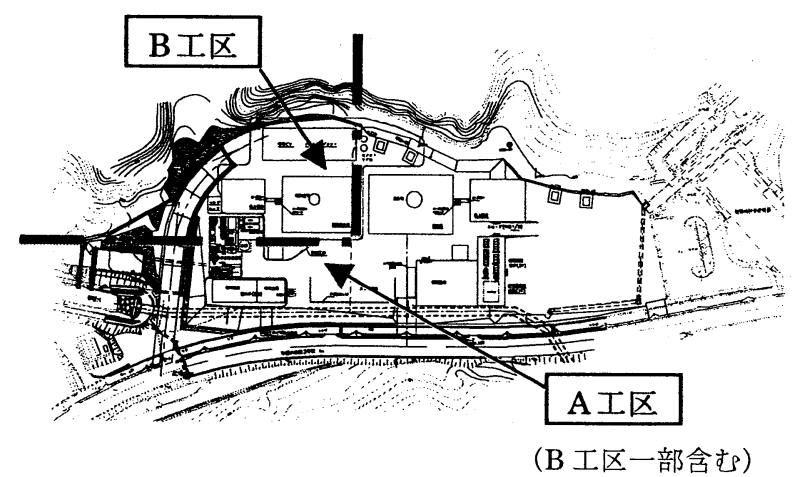

図-1 工事の工区割り詳細

地上施設などの両工区で共有する設備については, 仕様書，設計図書および積算資料において工区毎に 分担する内容を記した。例えば，コンクリートプラ ントについては設置・管理を B工区が担当し，その 後の運用にあたっては, 積算上, コンクリートの使 用量に応じて両工区で分担することとした。

a） A 工区（主立坑）の工事範囲

A 工区すなわち主立坑を中心とする工事の主な対

象範囲は，以下に示すとおりである。

(1)仮設備および坑内設備・坑外設備一式

- 主立坑巻き上げ機／櫓設備

- 給気 / 給水設備

- 排水設備

- 排水処理設備

- 換気設備

- 防音ハウス

・安全管理システム

・計測管理システム等

(2)主立坑 $\mathrm{L}=300 \mathrm{~m}$ (仕上り内径 $\phi 6.5 \mathrm{~m}$ )

(3)予備ステージ（仕上り径 $3.0 \mathrm{~m} \times 3.0 \mathrm{~m}$ 幌型）

(哚度 $100 / 200 / 300 \mathrm{~m}$ ) のうち $30.75 \mathrm{~m}$

b) B 工区（換気立坑）の工事範囲

B 工区すなわち換気立坑を中心とする工事の主な 対象範囲は，以下に示すとおりである。 
(1)仮設備および坑内設備・坑外設備 一式

- 換気立坑巻き上げ機・櫓設備

- 排水設備

- 換気設備

- 防音ハウス

- 電気設備

(非常用発電・フリッカー設備含む)

・コンクリートプラント設備

・計測管理システム等

(2)換気立坑 $\mathrm{L}=300 \mathrm{~m}$ (仕上り内径 $\phi 4.5 \mathrm{~m}$ )

(3)予備ステージ（仕上り径 $3.0 \mathrm{~m} \times 3.0 \mathrm{~m}$ 幌型）

（深度 $100 / 200 / 300 \mathrm{~m}$ ）のうち $9.25 \mathrm{~m}$

(4)扇風機坑道 $\mathrm{L}=29 \mathrm{~m}$ (仕上り内径 $\phi 1.94 \mathrm{~m}$ )

（横坑 $\mathrm{L}=4.4 \mathrm{~m}$ 含む，予備ステージと同断面）

\section{3. 入札方式}

(1) 背景

今回の工事は, 国家的なプロジェクトであること， 事業の規模やその内容から透明性の確保や競争原理 の導入が重要視されることから, 指名競争入札では なく，官報公示を行う一般競争入札とした。

（2）対応した内容

以下の 4 項目に対して，対応することとした。

a) 物品等又は特定役務調達契約審査委員会 (サイ クル機構内）に打ける審査

b）官報公示資料の作成・公示

c）入札説明資料の作成・説明会の開催

d）官報への入札結果の公示

国土交通省管轄の工事においては，工事内容と入 札説明書を同時に公示することが多いが，本件では 時間的制約から, 工事内容を公示し, 入札説明書は 別途配布することとした。

(3) 入札参加条件

立坑の深度が $1,000 \mathrm{~m}$ という国内外で施工事例が 極めて少ない工事であり（一期工事では立坑深度 $300 \mathrm{~m}$ までであるが, 掘削設備は深度 $1,000 \mathrm{~m}$ を当 初から想定して設置), かつ, 立坑の完成が工事の目 的ではなく, 研究のために掘削するという性質の工 事であるため，応札資格として，下記の条件を付し て応札者の資質を確保した。

立坑掘削の実績：(元請としての条件）

過去 20 年以内に, 深さ $200 \mathrm{~m}$ 以上, 内径 $4 \mathrm{~m}$ 以 上の立坑掘削工事の施工実績を有すること 研究の実績 :

高レベル放射性廃棄物の地層処分技術に関連す る哚地層の科学的研究に対して, サイクル機構
を含む 2 つ上の公的機関からの研究実績が有

り，専門知識を持つ研究者を従事させることが

できること

なお，条件を満たす施工会社は，入札の時点で 10 社程度以上あるものと想定された。

a) 深度に対する条件值

これまでの国土交通省の事例から判断すると，深 度に対する条件值には明確なルールは定義されてお らず，おおむね 50\%〜 100\%の範囲で設定されてい るのが実情である。また，図一 2 に示す立坑施工実 績の深度別度数分布 ${ }^{2)}$ によれば，深度 $200 \mathrm{~m}$ 以上に なると施工実績が急激に減少する傾向が見受けられ る。すなわち, 深度 $200 \mathrm{~m}$ 程度の立坑工事で得られ た知見はそれだけ貴重な情報であると考えた。

一方, 当該工事は哚度 $300 \mathrm{~m}$ （一期工事分）の大 深度立坑であり, 周辺岩盤や地下水への影響を考慮 した施工管理が必要であるとともに, 研究者や見学 者の入坑を伴うため, 安全面や工程面への配慮も重 要な管理項日となる。従って，当該工事には大哚度 立坑の施工実績または施工経験に基づいた知見を十 二分に活用することも重要な項目と考えた。

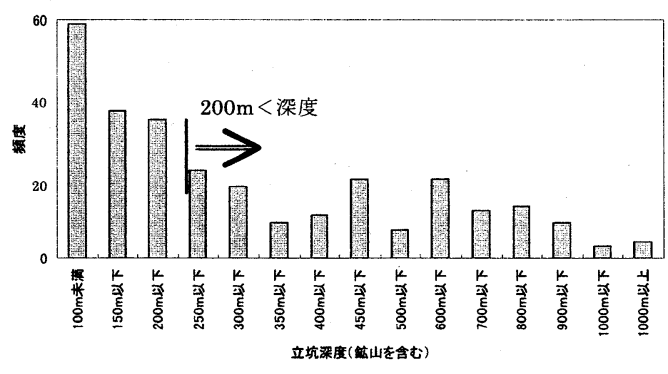

図 -2 立坑施工実績の深度別度数分布

以上の要件に，図-2 に示した過去の事例や施工 実績および当該工事の特徵を踏まえると，当該工事 の重要性を考慮して「深度 $200 \mathrm{~m}$ 以上の工事実績」 または「樑度 $200 \mathrm{~m}$ 以上の立坑工事経験者」が深度 に対する妥当な参加要件であると判断した。なお, 参加資格要件に深度 $200 \mathrm{~m}$ 以上の条件值を採用した 場合は, 入札対象深度 $(=300 \mathrm{~m})$ に対する比率が $67 \%$ $(=200 \mathrm{~m} / 300 \mathrm{~m})$ となる。一般的に，この值は，国 土交通省で採用されている比率 $(50 \%$ ～100\%) の範 囲内に収まっているため妥当と考えられる。

b) 内径に対する条件值

国土交通省の事例によると，図一 3 に示すとおり， 内径に対する条件值はおおむね $70 \%$ 100\%の間に 収まっている。また，これまでの施工実績 2)におい ても, 図一 4 に示すように $\phi 2 \mathrm{~m} \sim \phi 10 \mathrm{~m}$ の範囲に正 
規分布に近い形の結果となっている。内径は, 構造 物の要求機能によって決まるのが一般的であり, 内 径と施工の難易度には内径と深度の関倸ほど強い相 関が無いことに加え, 深度が深い場合, 内径の小さ い工事の方が施工的に難しいことから, 当該工事に は深度に対する条件値と同様に, 設計值の $70 \%$ を採 用するのが妥当と判断した。

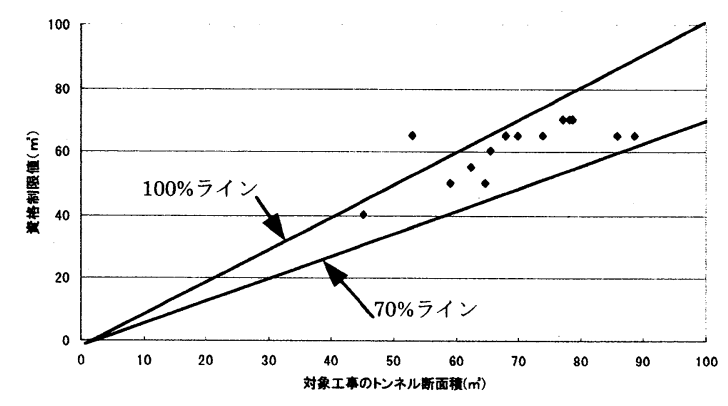

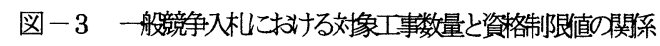
立 坑 数

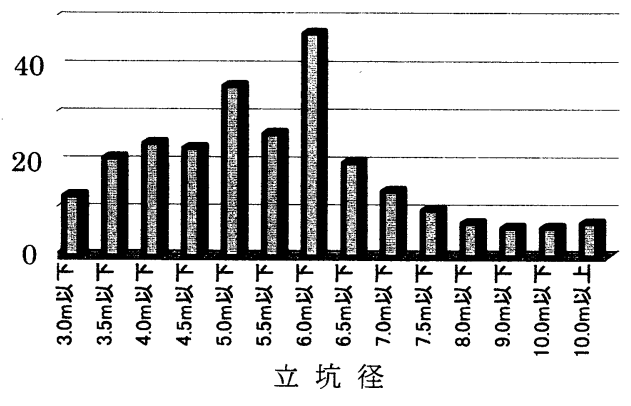

図-4 立坑径の分布（全数=259）

また, 主立坑 $(\phi 6.5 \mathrm{~m})$ と換気立坑 $(\phi 4.5 \mathrm{~m})$ で立坑内径が異なるため, 各々で参加資格要件を変 える方法も考えられるが, 前述したとおり, 内径が 大きいことによる施工難易度または内径と施工経験 に強い相関もないと考えられるため, 当該工事では 内径に対する条件值を $2 つ$ 立坑の平均值に対する $70 \%$ と考え,「内径 $4 \mathrm{~m}$ 以上」とした。

<参加資格要件と寸る内径の条件值 $>$ :

$(6.5 \mathrm{~m}+4.5 \mathrm{~m}) / 2 \times 70 \%=3.85 \mathrm{~m} \Rightarrow 4.0 \mathrm{~m}$

\section{4. 総合評価落札方式}

\section{(1) 背景}

研究所は, 深地層の研究施設としてわが国で初め て建設されものであることから，民間の最新技術を 導入することや透明性の確保および安全や環境対策 などを積極的に評価することを主な目的として，国 土交通省管轄の工事等で実施している総合評価落札
方式を採用することとした。採用にあたっては, 各 応札者の技術提案を受け付け, 提案内容と価格の両 方を加味したうえで落札者を決定する技術提案型の 契約方式とした。また, 本分野にかかわってきた施 工会社に多くの機会を与えるため, 本工事の発注に 関しては, 特定建設工事共同企業体（以下,JV) で 行うことを前提とした。

（2）検討した内容

国土交通省国土技術政策総合研究所による「公共 工事における総合評価落札方式の手引き·事例集 (第 1 集案)」3)において, 総合評価の評価項目は下記の とおり，設定されている。

(1)総合的なコストに関する事項

$$
\text { ライフサイクルコスト, その他（補償費等） }
$$

(2)工事目的物の性能, 機能に関する事項

性能, 機能

(3)社会的要請に関する事項

環境の維持, 交通の確保, 特別な安全対策, 省 資源対策又はリサイクル対策

当該工事において，上述の評価項目を受け付ける ことの妥当性を検討し，人身事故の発生がプロジェ クト全体の工程に大きく影響を与える可能性がある こと, 市街地に近接していること, 抢よび研究開発 が主目的であるという当該工事の特徴に対応させて, (1)安全対策, (2)環境保全対策および(3)地質観察方法 の 3 項目について技術提案を受け入れることとした。

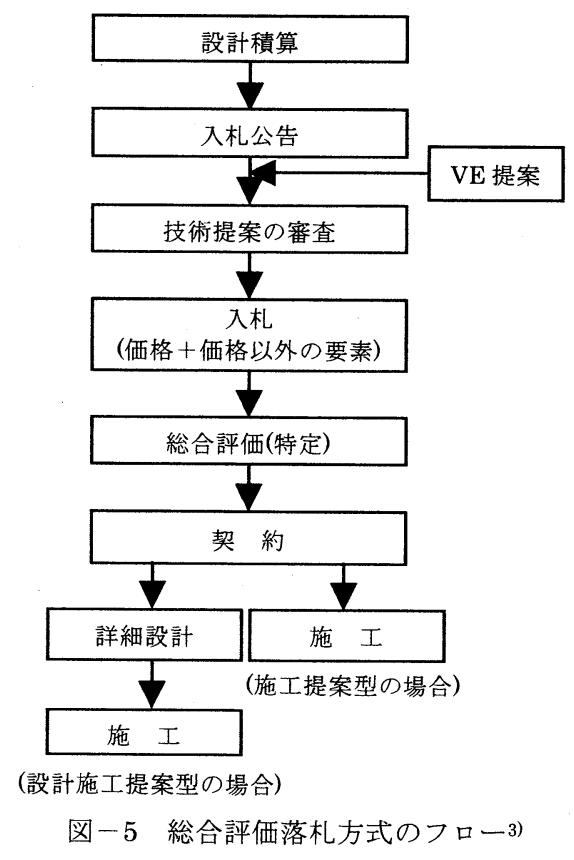

（3）落札方式の検討 
総合評価落札方式は, 図 -5 に示すフローで進め られ, 設計施工提案型の場合は, 詳細設計も含めて 行うものであるが，今回は施工提案型としている。 これは技術提案された内容を審査し, 内容に応じた 評価点を与え, 評価点と入札価格の両方を考慮して 落札者を決定するものである。評価点の付与の方法 については，いくつか考えられ一般的に提案項目の 性質に応じて決められる。そこで, 価格に換算可能 な事項については価格換算し, 換算が困難な事項に ついては点数評価をすることが適当と考え, 本件の 提案項目について, 3 段階程度の点数評価を行った。

(4) 技術提案内容の審査

各 JV から提案された内容は, 外部有識者を含め た「瑞浪超深地層研究所研究坑道掘削工事技術提 案・評価委員会」(以下, 評価委員会) に捺いて審査 した。審査に当たっては, 事前にサイクル機構内に 設置した事務局において，各 JV にヒアリングを実 施し, 提案内容をとりまとめ, その抜粋資料を委員 会に諮る方式とした。委員会のメンバーは，大学や 電力の専門家 4 名とサイクル機構内有識者 5 名の計 9 名とした。

(5) 評価

技術提案項目の抽出に際しては,スケジュール上, 十分な時間をかけることができなかった。

例えば，安全対策については，工区で視点を変え ての提案 (A 工区では調查研究者や見学者に対する 安全対策，B工区では施工に対する安全対策）を受 け付ける意図があったが, 結果的には提案内容が同 じものとなっている。その解消のためには, 例えば 評価委員会等の場を公示前に設けて事前議論を実施 し, 提案項目を抽出することにより, 実際の評価委 員会の運営もよりスムーズに行くものと想定される。

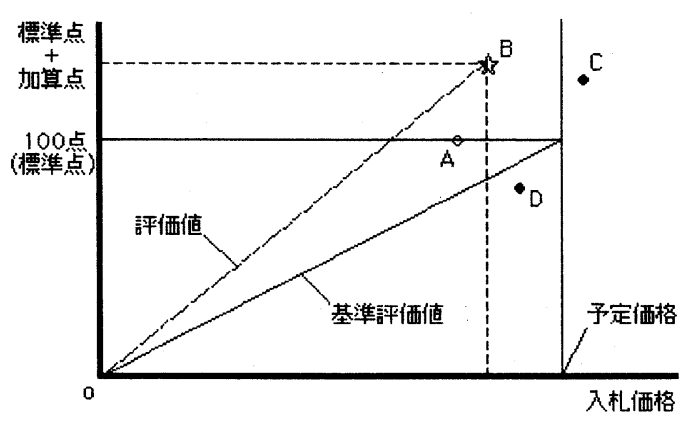

図 -6 総合評価方式の模式図

また, 総合評価落札方式の中で, 本工事で採用し た落札方法は, 工事費の予定価格は提案の内容に依 存せず定額であり, この予定価格以内で落札者が決 定される方式であった（図一6参照)。これは，予算
追加の措置が困難であることや，ライフサイクルコ ストや補償費といった金額換算が容易な提案項目で はなかったことによる。しかしながら，技術提案の 内容は結果的に金額換算が可能であり, 公平な意味 では, 提案内容に応じて工事費を増減させる方法が 本来は, 理想的である。このような契約方式におい ての今後の課題として，一般的に言われている技術 提案に必要な労力や時間のわりに工事費に反映され ず不公平であるといった受注者側の意見にも耳を傾 ける必要があるう。

\section{5 . 積算価格の事前公表}

(1) 背景

公共工事の予定価格の事前公表については, 談合 に対する発注者の関与の防止を主な目的として, 地 方自治体や特殊法人の契約の一部で実施されている。 国土交通省に扔いては，所轄する 11 の特殊法人に 対して予定価格に事前公表を試行するよう指示して いる 4)。サイクル機構に扔いても, 契約事務規程を 考慮し, 予定価格ではなく積算価格として税抜きの 価格を, 入札前に, 入札資格を与えられた JV に対 して公表することとした。

(2) 評価

積算価格の事前公表については一般的には賛否両 論があり, 弊害が想定される事項としては入札価格 の高止まりがある。この点についてはサイクル機構 として初めての試みであるため, 今後いくつかの工 事で試行するとともに, 他機関での実施例も参照と して, それらの結果と併せて評価する必要があると 考えられる。な拉, 評価方法ならびに加算点につい ては, サイクル機構で決め, 評価委員会に図った。

それぞれの工区での積算価格と落札価格の比すな わち落札率は $98 \%$ 前後となった。

\section{6. 入 札}

\section{(1) 入札方法}

当該工事は, 入札時に施工方法等の提案を受け付 け, 価格以外の要素と価格を総合的に評価して落札 者を決定する総合評価落札方式の工事である。入札 する方法としては, 標準案（設計図書や仕様書に示 された通り, 施工する方法) で入札を行う方法と, 代替案（技術提案内容を反映させて施工する方法） により入札を行う方法の 2 通りとし, いずれか一方 の方法を選択できるものとした。

（2）入札説明資料

入札における資料としては以下のものを準備した。 
- 入札説明書

- 入札資料（仕様書・設計図面・内訳書）

. 技術資料様式（施工実績 - 主任技術者等）

- 技術提案様式（基本性能条件・落札条件 - 提 案項目・代替案）等

(3) 入札スケジュール

研究坑道工事における入札までのフローを図 -7 に示す。

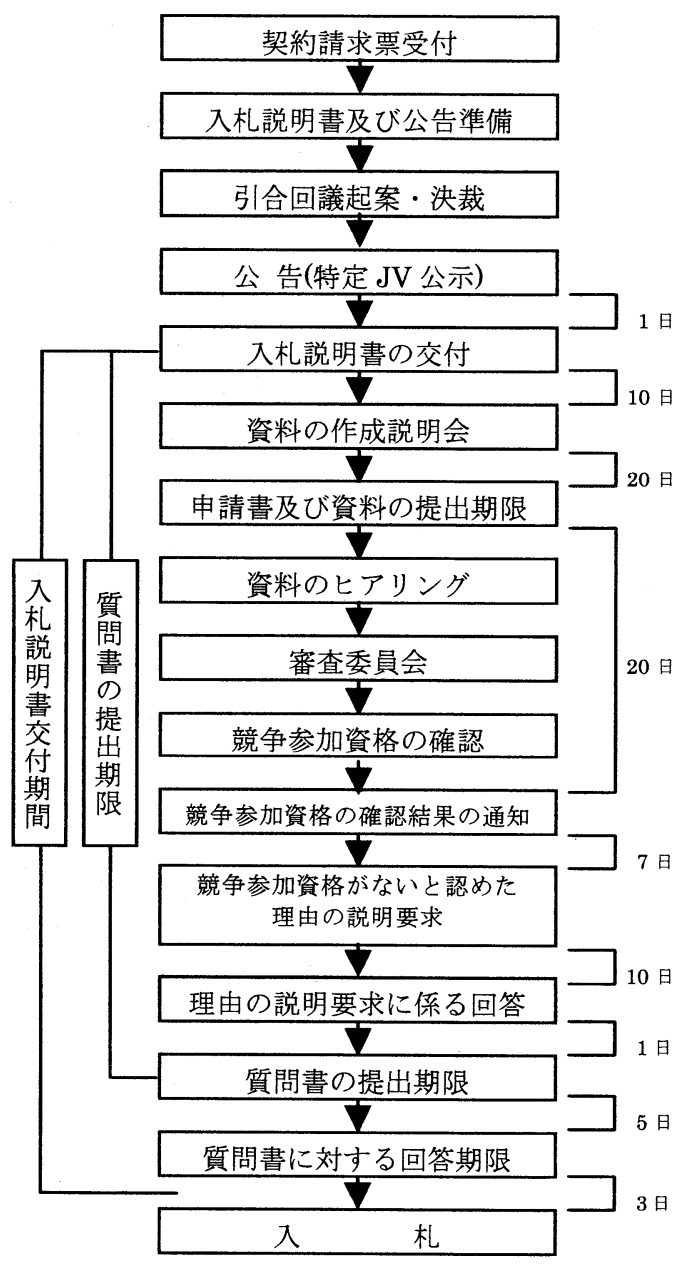

(4) 技術提案書の条件

図-7 入札フロー

技術提案採用の前提としては, 施工計画および施 工方法の提案あるいは設計および施工方法の提案が 適正であることが第一である。また，「代替案」での 協議が整わないと判断された場合には不採用とする こととした。

技術提案書の提出にあたって, 入札説明書 - 入札 資料（仕様書・設計図面・内訳書）による「標準案」 に代わる代替案に基づき施工を行う場合は，その内 容を示した施工計画書を提出させるものとした。そ の施工計画が認められない場合は, 標準案で施工す
る意思の確認を行うこととした。また, 標準案に基 づいて施工しようとする場合は, 標準案による施工 計画を提出させるものとした。

（5）落札者の決定方法

競争参加資格の確認通知において, 設計および施 工方法の代替案により競争資格を認められた者は, 当該提案に基づく提案を行い，技術提案の採否で否 とされた者で, 標準案に基づく施工方法により, 競 争参加資格を認められた者は, 標準案に基づいて入 札を行う。これらの者の中で,「総合評価落札方式」 によって得られた数値の最も高い者を落札者とした。 ただし，落札者となるべき者の「評価值」によっ ては，その者では当該契約の内容に適合した履行を しないおそれがあると認められるとき，または，そ の者との契約ができない状況の場合には, 適切な「評 価値」と考えられるもののうち高い「評価値」の順 をもって入札した者を落札者とすることとした。

（6）代替案の場合における契約変更の取り扱い

代替案で入札を行った者は，落札者が作成した実 施設計をサイクル機構の承諾を得て, 実施設計に基 づいた当該工事の施工範囲・内容で設計図書を変更 するものとした。ただし，請負代金の変更は行わな いものとした。受注後における契約変更の取り扱い については, 一部を除いて契約変更の対象とした。 さらに, 請負金額の変更に際しては, 代替案と標準 案との工法比較により, 標準案の範囲内で変更する ものとした。代替案の個々の工法によるリスク（被 害対応）との比較対象とならない代替案の独自リス クについては, 落札者の負担とするものとした。

また, 落札者の責により提案された代替案の施工 を履行できない場合は, 工事成績評定を減じる処置 を行う可能性があることを示唆した。

\section{JVからの技術提案書とその評価}

（1） 入札参加者加ら提出資料

入札参加者加の資料としては, 以下の書類を提 出させるものとした。

・ 競争参加確認申請書

- 競争参加資格確認資料

- 特定建設工事共同企業体協定書および委任状

・施工実績

- 研究受託実績

- 主任（監理）技術者等の資格·工事経験

・設計技術者の資格

- 契約書の写し（施工実績・研究受託実績）

・技術提案項目一覧 
・ 安全対策に関する代替提案

・環境保全対策に関する代替提案

・ 地質観察の方法に関する代替提案

. 代替案類似実績

- 施工計画

(2) 技術提案

工事は，A工区および B 工区に分けて入札を行っ たが，ここでは A 工区を代表事例として述べること とする。技術提案項目としては，基本設計を大きく 変えることがなく，工事特性や工事環境を鑑みて， 最新の技術や社会的要請に関する項目および効率的 な作業が行える項目すなわち，当該工事の特徵であ る(1)安全対策, (2)環境保全対策, (3)地質観察方法と した。

\section{a) 標準案}

仕様書に示した標準案の特徵的部分を示すと，下 記のとおりである。

(1) 安全対策（調査・研究者, 見学者の安全対策）

立坑坑口における入出坑管理および入坑者の位置 確認が可能であることを第一としている。また，坑 内火災の発生の確認が可能であり，坑内環境および 換気設備の制御ができ，坑内状況を把握できること
とする。これらは，地上にて確認や制御が可能なも のを評価の指標とした。

1）入出坑管理システム

・ID タグ方式

・ 人体感知センサー

2）坑内火災管理システム

・ 一酸化炭素センサー・煙探知センサー

- 風門, 非常通報装置, 換気ファン作動確認

- 消火設備作動確認

3）坑内環境管理システム

- 温湿度・風速・気圧センサー

4）坑内通信監視システム

- 電話

・監視カメラ

- 一斉通報スピーカ・回転灯

(2) 環境保全対策（排水の水質保全対策）

排水処理設備は，処理能力 $100 \mathrm{~m}^{3} / \mathrm{h}$ の設置とし た。水質保全対策として，水質污濁防止法ならびに 県の生活環境の保全に関する環境基準と第 5 次水質 総量規制を満足させた上で，下流の利水者への影響 の可能性の低減度合いを指標とした。

表 -1 技術提案の概要

\begin{tabular}{|c|c|c|c|c|c|c|c|c|c|c|}
\hline \multirow{2}{*}{$\begin{array}{l}\text { 工 } \\
\text { 区 }\end{array}$} & \multirow{2}{*}{ 提案項目 } & \multicolumn{3}{|r|}{ JV その1 } & \multicolumn{3}{|c|}{ JV その2 } & \multicolumn{3}{|c|}{ JV その3 } \\
\hline & & $\begin{array}{l}\text { 代替 } \\
\text { 案 }\end{array}$ & 実績 & 内 容 & $\begin{array}{l}\text { 代替 } \\
\text { 案 }\end{array}$ & 実績 & 内 容 & $\begin{array}{c}\text { 代替 } \\
\text { 案 }\end{array}$ & 実績 & 内 容 \\
\hline \multirow{10}{*}{$\begin{array}{l}\text { A } \\
I \\
\text { 区 }\end{array}$} & 1) & (t) & 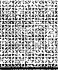 & X) & $+\frac{1}{4}$ & 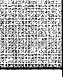 & 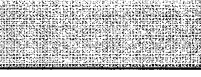 & 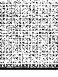 & (1) & 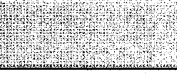 \\
\hline & (1)入出坑管理システム & O & O & 代替方式の採用 & 0 & $\times$ & 代替方式の採用 & O & 0 & 仕様(機能)の追加 \\
\hline & (2)坑内火災管理システム & 0 & O & 仕様(項目)の追加 & O & $x$ & 仕様(項目)の追加 & - & - & \\
\hline & (3)坑内環境管理システム & O & O & 仕様(項目)の追加 & 0 & $x$ & 仕様(項目)の追加 & - & - & \\
\hline & (4)坑内通信監視システム & O & 0 & 代替方式の採用 & O & 0 & 代替方式の採用 & 0 & O & 仕様(数量)の追加 \\
\hline & (2) (1) & (3) & (1) & (2) & 4 & 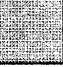 & (1) & 年 & $1+8$ & (1) \\
\hline & (1)排水処理設備の設置 & 0 & 0 & 仕様(数量機能)の追加 & 0 & $x$ & 仕様(機能)の追加 & 0 & 0 & 標準案+リサイクル \\
\hline & 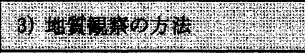 & 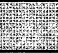 & (1) & (2) & 15 & t. & & 12. & 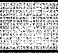 & 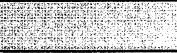 \\
\hline & $\begin{array}{l}\text { (1)坑道壁面の観察および } \\
\text { 写真撮影 }\end{array}$ & 0 & $x$ & 仕様(機能)の追加 & $\mathrm{O}$ & $x$ & 仕様(機能)の追加 & - & - & \\
\hline & (2)坑道壁面の湧水量測定 & O & $x$ & 仕様(数量)の追加 & O & $x$ & 仕様(数量)の追加 & - & - & \\
\hline \multirow{7}{*}{$\begin{array}{l}\text { B } \\
\text { 工 } \\
\text { 区 }\end{array}$} & 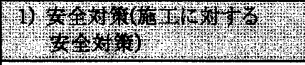 & I & III) & & 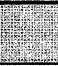 & r. & & 78 & $=$ & \\
\hline & (1)入出坑管理システム & 0 & 0 & A 工区と同じ & $\mathrm{O}$ & $x$ & A 工区と同じ & 0 & 0 & A 工区と同じ \\
\hline & (2)坑内火災管理システム & - & - & & 0 & $x$ & A エ区と同じ & - & - & \\
\hline & (3)坑内環境管理システム & O & O & A エ区と同じ & O & $x$ & A工区と同じ & - & - & \\
\hline & (4)坑内通信監視システム & 0 & 0 & A エ区と同じ & O & O & A 工区と同じ & 0 & O & A エ区と同じ \\
\hline & 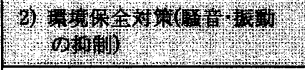 & & I & & 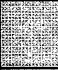 & 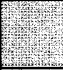 & & & & \\
\hline & (1)防音ハウスの設置 & O & O & 仕様(項目)の追加 & 0 & $O / x$ & 標準案+発生源対策 & - & - & \\
\hline
\end{tabular}


(3) 地質観察の方法

坑道壁面の地質学的および水理学的情報を確実か つ合理的に取得できる方法とする。

1）坑道壁面の観察および写真撮影

・ $\mathrm{CCD}$ (or デジタル)カメラ等による撮影

・壁面マッピング・地質記載

2）坑道壁面の湧水量測定

・壁面の湧水量測定

・ウォータリングにおける自動計測

b) 技術提案の内容

提出された提案技術の概要比較を表一 1 に示す。 なお, 応札者は, すべて 3 社からなる JVであった。

提案技術の内容（A工区の例）を示すと, 以下の 通りである。なお，採用された技術提案は，A工区 およびB工区相互に採用することとした。すなわち， A 工区（B工区）で採用された技術提案は，B工区

（A工区）においても展開することとし, その内容 は追加仕様書として契約書に含めた。

(1) 安全対策

入出坑管理および通信設備と共有できる代替方式 を採用することで，費用対効果を向上させた。坑内 火災管理システムおよび環境管理システムについて は，仕様項目を増やすこととした。

(2) 環境保全対策

故障時にも処理能力が確保できるように, 排水処 理設備の数量・機能を変更することで, 機能維持と 修復の余裕を確保することとし, 水質向上のための システムとすることにした。

(3) 地質観察の方法

壁面観察撮影における連続する展開画像として加 工でき，立体的な分布状況を示すことができるもの

表-2 総合評価落札汸刘象項目およひ加算点の算出方法 (A凹区)

\begin{tabular}{|c|c|c|c|c|c|c|c|}
\hline 大項目 & 小項目 & 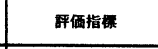 & 醋䇲技㭪 & \begin{tabular}{|c|} 
提察の \\
青無 \\
\end{tabular} & 畔䤄点 & 重み & 合算 \\
\hline \multirow{4}{*}{ 责全対策 } & \multirow{4}{*}{ 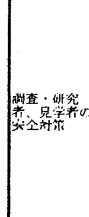 } & \multirow{4}{*}{ 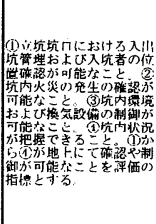 } & 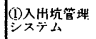 & o & 2 & \multirow{4}{*}{0.5} & \multirow{4}{*}{4} \\
\hline & & & 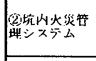 & 0 & 2 & & \\
\hline & & & 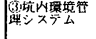 & 0 & 2 & & \\
\hline & & & 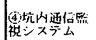 & 0 & 2 & & \\
\hline 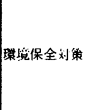 & 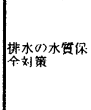 & 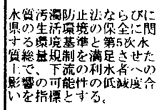 & 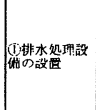 & 0 & 2 & 2 & 4 \\
\hline \multirow{2}{*}{ 地他视繁の方法 } & \multirow{2}{*}{ 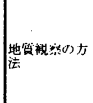 } & \multirow{2}{*}{ 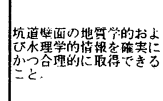 } & 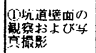 & 0 & 2 & \multirow{2}{*}{0.5} & \multirow{2}{*}{2} \\
\hline & & & 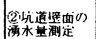 & 0 & 2 & & \\
\hline \multicolumn{5}{|c|}{ 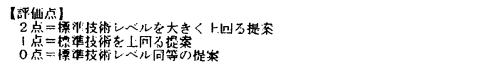 } & \multicolumn{2}{|c|}{ 加算点 } & 10 \\
\hline
\end{tabular}

とした。また, 湧水量測定においては, 代替案とし て簡便な方法を用いることで測定間隔を小さくする こととした。

c）技術提案評価委員会での評価

本工事の総合評価落札方式は, 工事価格と性能のみ を評価することとし，評価項目について，標準案に よる施工方法については標準点を付加し, 代替案に よる施工方法については, その達成度に応じて加算 点を加えて総合的に評価する方法とした。

具体的な評価項目の加算点の評価方式は, 各評価 項目の内容に応じて重み付けを行い, 加算点の合算 が 10 点となるよう設定した。各評価項目について の加算点の評価点・重みを表一2（A 工区）执よび 表一3（B 工区）に示す。各評価項目に付加する点 数は，それぞれ下記のとおりとした。

2 点 $=$ 標準技術レベルを大きく上回る提案

1 点 $=$ 標準技術レベルを上回る提案

0 点 $=$ 標準技術レベルと同等の提案

表-3 総合評西落札方式刘象項目およひ为㔍点の算出汸法 (BIX)

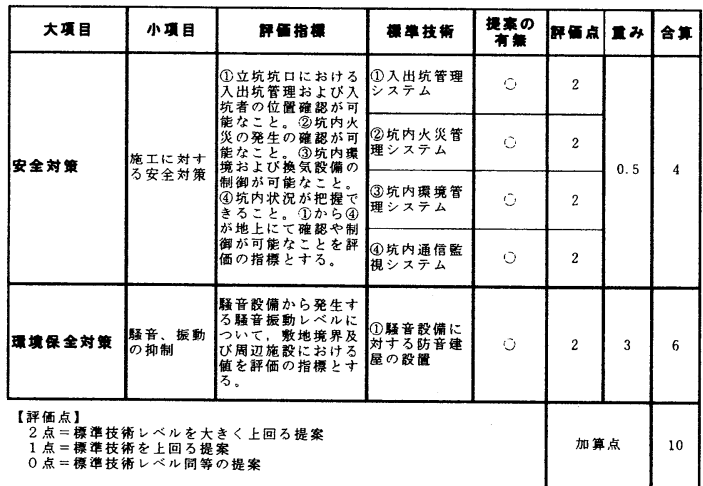

研究坑道工事の契約に抒いて採用した総合評価落札 方式は，各 J V の技術提案を受け付け，提案内容と 価格の両方を加味した上で落札者を決定するものと

表 -4 提案技術の採点結果（A工区）

\begin{tabular}{|c|c|c|c|c|c|c|c|}
\hline 大頸目 & 小項目 & 提案頔目 & 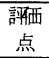 & 動 & $\begin{array}{l}\text { JV } \\
\text { क1 }\end{array}$ & $\begin{array}{l}J \sqrt{N} \\
\text { の2 }\end{array}$ & $\begin{array}{l}\mathrm{JV} \\
\text { の3 }\end{array}$ \\
\hline \multirow{4}{*}{$\begin{array}{l}\text { 安全対 } \\
\text { 策 }\end{array}$} & \multirow{4}{*}{$\begin{array}{l}\text { 調査·研究 } \\
\text { 者, 兒学者 } \\
\text { の安全対 } \\
\text { 策 }\end{array}$} & 入斗拕筫理ミステム & 2 & \multirow{4}{*}{05} & 1 & 1 & 0 \\
\hline & & 坑内坐级管理 ススム & 2 & & 1 & 0 & 0 \\
\hline & & 坑大環竟智理ステム & 2 & & 1 & 1 & 0 \\
\hline & & 坑大通籃視 スステム & 2 & & 1 & 1 & 1 \\
\hline $\begin{array}{l}\text { 環境保 } \\
\text { 全䍃策 }\end{array}$ & $\begin{array}{l}\text { 排水の水 } \\
\text { 質保全対 } \\
\text { 策 }\end{array}$ & 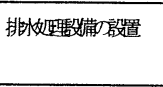 & 2 & 2 & 2 & 1 & 1 \\
\hline \multirow{2}{*}{$\begin{array}{l}\text { 地質観 } \\
\text { 祭佉法 }\end{array}$} & \multirow{2}{*}{$\begin{array}{l}\text { 地筫観察 } \\
\text { 方法 }\end{array}$} & 坑道顔的矱察 & 2 & \multirow{2}{*}{05} & 2 & 1 & 0 \\
\hline & & 坑道湎的愑水浿 & 2 & & 1 & 1 & 0 \\
\hline & & & \multicolumn{2}{|c|}{ 加算点 } & 7.5 & 45 & 25 \\
\hline
\end{tabular}


表 -5 提案技術の採点結果（B工区）

\begin{tabular}{|c|c|c|c|c|c|c|c|}
\hline 大頑目 & 小瓔 & 提案頑目 & $\begin{array}{c}\text { 評西 } \\
\text { 点 } \\
\end{array}$ & 重队 & $\begin{array}{l}\mathrm{NVZ} \\
01\end{array}$ & $\begin{array}{l}J \sqrt{2} \\
\text { の2 }\end{array}$ & $\begin{array}{l}J \mathcal{Z} \\
93 \\
\end{array}$ \\
\hline \multirow{4}{*}{$\begin{array}{l}\text { 安全対 } \\
\text { 策 }\end{array}$} & \multirow{4}{*}{$\begin{array}{l}\text { 調查·研究 } \\
\text { 者, 見学者 } \\
\text { の安全対 } \\
\text { 策 }\end{array}$} & 入出扩筫理スステム & 2 & \multirow{4}{*}{0.5} & 1 & 1 & 0 \\
\hline & & 坑内人从䌽管理ンステム & 2 & & 0 & 0 & 0 \\
\hline & & 坑大環竟穊理、ステム & 2 & & 1 & 1 & 0 \\
\hline & & 坑内通盖視 スステム & 2 & & 1 & 1 & 1 \\
\hline $\begin{array}{l}\text { 環境保 } \\
\text { 金策 }\end{array}$ & 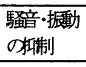 & 防音ウススの設置 & 2 & 3 & 1 & 1 & 0 \\
\hline & & & \multicolumn{2}{|c|}{ 加算点 } & 45 & 45 & 0.5 \\
\hline
\end{tabular}

した。技術提案の内容については，評価委員会にお いて審査することとした。その採点方法には，(1)全 員協議により意思決定する方法, (2)各委員の採点結 果を計算し決定する方法 (平均点の採用等), (3)事務 局案を紹介し承諾する方法があるが, サイクル機構 として初めてのケースであるため, 評価委員会とし ての判断の統一性や客観性を重視し, 全員協議によ る方法を採用することとした。なお，委員間で意見 が分かれた場合には, 最終決断を主査の判断にゆだ ねることとした。当初, 項目ごとに全員協議により 採点する方法にて進めたが，採点までに時間がかか ることから, 最終的には, 提案内容をすべて紹介し 評価委員会で議論したのちに, 各委員が採点し, そ の結果を協議する方法とした。

提案技術の内容は表一1（前述）に総括してある が，その提案技術の採点結果を表 -4 掞よび表 -5 に示す。また，その後の入札とあわせた入札結果を 図-7 に示寸。図中に示寸と扔り，A 工区について は JV その 1 が，B 工区については JV その 2 案が 落札した。これにより, JV その 1 が提案した A 工 区の技術と,JVその 2 が提案した B工区の技術が， $\mathrm{A} \cdot \mathrm{B}$ 両工区に掞いて採用されることとなった。

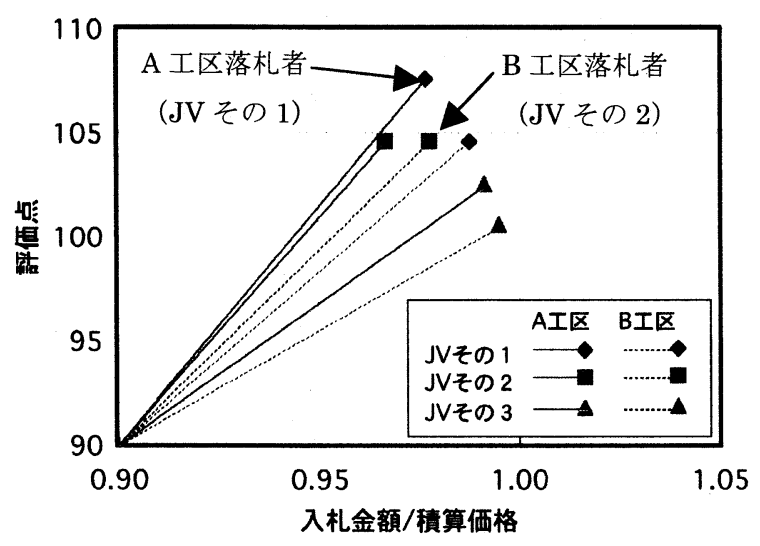

図 -7 入札結果

\section{8.おわりに}

研究坑道工事は, 平成 15 年 3 月 12 日に契約とな り, 現在, 写真 -1 (工事全体概要) および写真 -2 （主立坑の施工状況）に示寸と抢り, 本格的に立坑 掘削が開始された段階である。

立坑 2 本の工事を工区分けして，それぞれについ て技術提案を受け付け, 総合評価落札方式により入 札した結果, 落札した JV の提案技術が相互に反映 され，より安全で環境保全に配慮した施工が可能な 準備が整った。また, 本研究坑道工事の目的の一つ である地質観察について, より高度な情報を取得で きる技術が採用された。

今後は, 工事進渉に応じて提案された技術を評価 する必要がある。これらの事項については, サイク ル機構として初めての試みであったことにより多く の労力と時間を要したが，この経験を継承すること により次回以降はより少ない労力と時間で対応が可 能と考えられる。さらに，入札後 VE（あるいは施 工段階 VE）と組み合わせることにより，高い品質 の工事が期待できるものと考えており，これについ ては今後の課題である。

\section{参考文献}

1）今津雅紀 - 佐藤稳紀 - 坂巻昌工 : 地下 $1,000 \mathrm{~m}$ の立坑 工事に着手 瑞浪超深地層研究所研究坑道工事, トン ネルと地下, vol.34, No.6, pp.37-48, 2004.6

2）坂巻昌工・佐藤稔紀・見掛信一郎・今津雅紀 : 国内に おける立坑・斜坑のデータベース化と瑞浪超深地層研 究所の立坑内径, 土木学会第 58 回年次学術講演会, VI-046, pp.91-92, 2003.9

3）国土交通省国土技術政策総合研究所：公共工事におけ る総合評価落札方式の手引き・事例集（第 1 案集）, 2002.7

4） 日刊建設工業新聞: 摇れる入札制度 予定価格'公表の 波紋”，日刊建設工業新聞紙，2002.4.10 


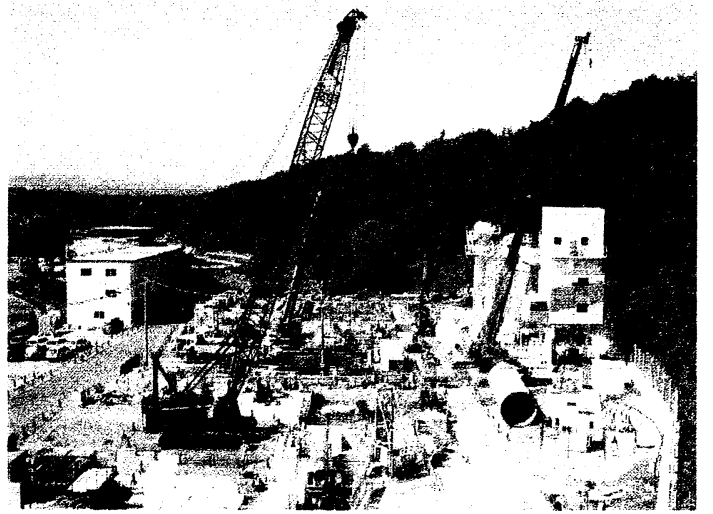

写真-1 研究坑道工事の全体状況 (平成 16 年 5 月現在)

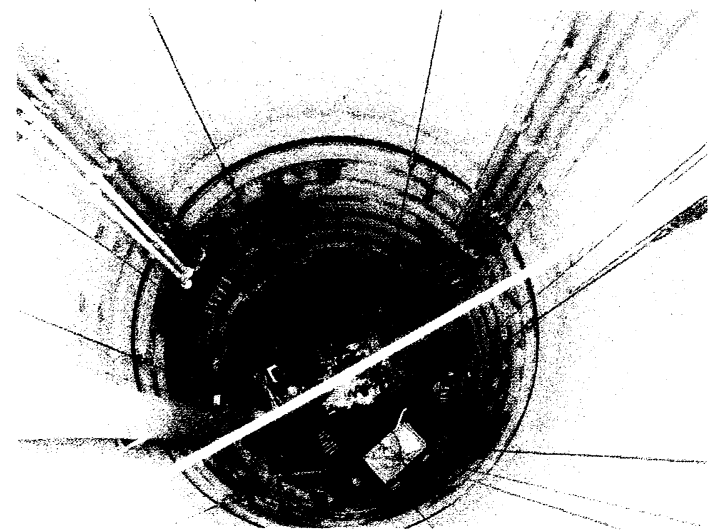

写真 -2 主立坑の施工状況

(深度 $17 \mathrm{~m}$ 付近)

\section{Total Evaluation Method in Bidding of}

\section{Mizunami Underground Research Laboratory Project}

Construction of two $1,000 \mathrm{~m}$ deep shafts and several drifts has been started for Mizunami Underground Research Laboratory Project, which is expected to contribute to the establishment of scientific basis for geological disposal of high-level radioactive waste. In order to enhance the technology and safety in this construction work, total evaluation method, which Land, Infrastructure and Transport Ministry of Japan has been applied to several public works, was applied to the open bidding of this project. The whole construction work was divided into two areas, and in the bidding, bidders were required to present technical proposals, which were reflected to contract documents for another construction area. This paper describes details of bidding system applied to the construction work of Mizunami Underground Research Laboratory. 